\title{
Effects of a Sport Education Model-Based Teaching Intervention on Students' Behavioral and Motivational Outcomes within the Physical Education Setting in the COVID-19 Scenario
}

\author{
Evelia Franco $^{1}\left[{ }^{\mathbb{D}}\right.$, Carlota Tovar ${ }^{2}$, Alba González-Peño ${ }^{1,2, * \mathbb{D}}$ and Javier Coterón ${ }^{2}$ \\ 1 Departament of Education, Research and Evaluation Methods, Faculty of Social and Human Sciences, \\ Universidad Pontificia Comillas, 28049 Madrid, Spain; efalvarez@comillas.edu \\ 2 Social Sciences Applied to Physical Activity, Sport and Leissure Department, Faculty of Physical Activity and \\ Sports Sciences-INEF, Universidad Politécnica de Madrid, 28040 Madrid, Spain; \\ carlotatov@hotmail.com (C.T.); j.coteron@upm.es (J.C.) \\ * Correspondence: alba.gonzalez.peno@alumnos.upm.es
}

Citation: Franco, E.; Tovar, C.; González-Peño, A.; Coterón, J. Effects of a Sport Education Model-Based Teaching Intervention on Students' Behavioral and Motivational Outcomes within the Physical Education Setting in the COVID-19 Scenario. Sustainability 2021, 13, 12468. https://doi.org/10.3390/ su132212468

Received: 26 September 2021

Accepted: 10 November 2021

Published: 11 November 2021

Publisher's Note: MDPI stays neutral with regard to jurisdictional claims in published maps and institutional affiliations.

Copyright: (c) 2021 by the authors. Licensee MDPI, Basel, Switzerland. This article is an open access article distributed under the terms and conditions of the Creative Commons Attribution (CC BY) license (https:/ / creativecommons.org/licenses/by/ $4.0 /)$.

\begin{abstract}
The sport education model (SEM) has been suggested to have a positive impact on students' motivational processes within the physical education setting. However, there is no evidence about how this methodology can affect such processes in the unconventional scenario provoked by the COVID-19 pandemic. The aim of the present study was to analyze the effect of a SEM-based teaching intervention on students' basic psychological needs (BPN), intrinsic motivation, and behavioral engagement in physical education. For this purpose, a quasi-experimental study was carried out in which two groups of secondary students $\left(\mathrm{M}_{\mathrm{age}}=14.61, \mathrm{SD}=0.5\right)$ were taught a basketball unit following either the SEM or traditional teaching. Previously validated questionnaires were administered both before and after the intervention. The results showed that students following the SEM methodology significantly improved their autonomy satisfaction (MPre $=3.09$ vs. Mpost $=3.63$ ), competence satisfaction (Mpre $=3.48$ vs. Mpost $=4.17)$, and relatedness satisfaction (MPre $=3.79$ vs . MPost $=4.43)$, as well as their behavioral engagement $($ MPre $=4.05$ vs. MPost $=4.48)$, while students in the control group reported lower relatedness satisfaction after $(M=3.54)$ than before $(M=4.13)$ the intervention. This study thus contributes to the understanding of how teaching in a COVID-19 scenario has affected students' motivational responses, and interesting implications for the current situation are provided.
\end{abstract}

Keywords: sport education model; basic psychological needs; methodology; COVID-19

\section{Introduction}

\subsection{Behavioral Engagement in Physical Education}

The physical education (PE) class has been pointed out as an ideal environment to enhance physical activity practice as well as the acquisition of healthy lifestyles among teenagers [1]. This fact explains that the promotion of students' engagement in PE classes through high-quality learning processes has become an important concern for teachers and researchers [2,3].

Engagement has been characterized by behavioral, emotional, and cognitive aspects [4] that affect students' attitudes and actions. Hence, students will be engaged when they enjoy the activities proposed, persist in the task, listen or answer teacher questions $[5,6]$. However, a student that is not engaged will give up easily, not display persistence or effort, get bored, or not listen to the teacher [7]. In this line, and highlighting the importance of the PE setting, behavioral engagement has been pointed out by different authors as a key concept to predict students' learning and performance achievement [8], by suggesting a positive consequence of the type of interactions that take place between teachers and students [9]. There is evidence that the behavioral engagement displayed by students in PE can be affected by their motivational processes $[10,11]$. 


\subsection{Motivational Processes in Physical Education through a Self-Determination Lens}

According to Geen [12], motivation is considered a fundamental psychological factor and it explains the direction, intensity, and persistence of behaviors. Specifically, in the PE context, motivation could affect students' attitudes and predisposition towards the task or activities proposed, and also towards relationships with their peers or teacher.

Considering the above, it is easy to understand the relationship between motivation and several students' positive outcomes in physical education. For instance, it has been found that students' motivation within the PE context is associated with effort exertion, enjoyment, or the intention to be physically active when finishing high school $[13,14]$.

Many of the studies addressing the understanding of students' motivation in PE have relied on the self-determination theory (SDT; [15,16]). According to the SDT [17], motivation lies on a continuum that ranges from higher to lower levels of self-determination (the degree to which behaviors are volitional). A person's optimal psychological development happens when what he or she does is aligned with what he or she wants; that is, when he or she experiences intrinsic motivation towards the activity they are doing. SDT distinguishes three basic psychological needs (BPN; autonomy, competence, and relatedness) that are assumed to directly enhance psychological and physical wellbeing [18]. Autonomy can be defined as one's need to feel responsible and/or as the owner of one's own behavior. In the PE setting, students can feel autonomous when they feel the origin of their actions or when they feel they have a say on what happens in the class. Competence can be fulfilled when experiencing effectiveness in one's interactions with the world. In the PE setting, the need for competence is based on trying to control the outcome and to experience efficacy in their participation and experiencing efficacy in their participation during the proposed activities. Lastly, relatedness refers to a need for connectedness with significant others [18]. In the PE context, this is the need to relate to and care for others and is defined by two dimensions: feeling accepted and being intimate with both peers and the teacher.

Motivational processes among students are likely to be affected by the interactions happening in the PE context. In this regard, the use of certain methodologies in which the focus has shifted from the teacher and instruction to the student and learning have been found to be associated with the adaptive motivational outcomes [19-21]. The sport education model (SEM; [22]) has emerged as an interesting methodological approach when it comes to fostering students' motivation $[23,24]$.

\subsection{The Sport Education Model's Characteristics}

The SEM is an instruction model that was first designed to deliver sport contents within the PE context. According to Siedentop [22], the model is defined by six fundamental characteristics: seasons, affiliation, formal competition, culminating events, record keeping, and festivity. Season refers to the real representation that a curriculum should have to better reflect the nature of sport, for example, with didact units longer than ordinaries. According to Siedentop [25], covering fewer activities in greater depth can result in better educational outcomes. Affiliation refers to students' feelings about taking part of a team or belonging to a single group, which will allow them to encourage social abilities and manage possible conflicts that may arise during the activities. This feature would thus be contributing to the social meaning derived from sport experiences. The seasons are defined by a schedule of formal competition, which, together with affiliation, provides the student the opportunity for planning and fosters the creation of a context for pursuing important goals for students. Culminating events recreate one typical feature of sport, which is finding out who is best for a particular season as well as how all participants have performed. These events are an opportunity for festivals and celebration of accomplishments. Record keeping is fundamental as it allows for the provision of feedback for individuals and teams and can act as a standard to define new goals. Recording performance through co-evaluation or shared evaluation will motivate and encourage the participation of the students. Lastly, festivity must be present through the season, and especially in the final event, to celebrate 
improvement, trying hard, and playing fairly. There are several tools such as posters, player introductions, or award ceremonies that are helpful to enhance this feature.

It has been suggested to provide richer experiences than traditional PE approaches due to its focus on transferable skills, social competences, or applicable knowledge [25,26]. Recently, different studies have found that the implementation of this methodology can bring specific benefits for students such as social development and inclusion [27], content learning and development of responsibilities [28], intercultural understanding and friendship goals [29], or teamwork abilities [30]. Interestingly, a recent study indicated that, regardless of the adaptations that different teachers might make to implement the SEM, the use of this methodology can provide quality learning experiences to students [31]. The existing literature has also suggested that the implementation of the SEM in PE might lead to positive motivational outcomes, such as intrinsic motivation [32] or BPN satisfaction [21,33,34], even among those less intrinsically motivated students [35].

Considering the above, there is previous evidence that the implementation of SEM experiences in PE settings can foster students' motivation $[19,21,24]$. However, research addressing this topic was carried out before the COVID-19 pandemic. The new scenario provoked by the aforementioned pandemic has brought important changes to the PE setting in terms of content reorganization, evaluation, and methodologies [36-38]. Furthermore, it is widely accepted that this situation has had an important psychological impact on the youth population $[39,40]$.

The present study aims to analyze the effect that an intervention based on the SEM, which was developed in a COVID-19 scenario, had on students' BPN satisfaction, intrinsic motivation, and behavioral engagement. This study thus adds to the existing literature by answering the following question: can a SEM unit developed in the COVID-19 scenario facilitate students' behavioral engagement and adaptive motivational patterns? It is hypothesized that, despite the changes brought to the PE setting due to restrictions provoked by COVID-19, a SEM-based experience can positively impact adaptive students' motivational outcomes as well as students' behavioral engagement.

\section{Materials and Methods}

\subsection{Participants}

The sample was composed of 50 high school students ( 28 boys and 22 girls) aged between 14 and 15 years old $(\mathrm{M}=14.61 ; \mathrm{SD}=0.5)$ from a secondary school in Madrid (Spain). According to teachers' report, the participants could be considered to be of medium socio-economic status, and there was a low rate of immigrants in the participant classes $(>5 \%)$.

The participants were divided into two groups: an intervention group $(n=25,48 \%$ girls) and a control group ( $n=25,40 \%$ girls). The University Ethics Committee gave their consent to conducting the present study, and the researchers followed the ethical guidelines and recommendations of the American Psychological Association [41], including obtaining written consent from the families of all participants.

\subsection{Design and Procedure}

A pre-post, quasi-experimental design was used in which the participants were divided into the control and experimental groups. It was not possible to incorporate randomization as there were two natural classes already established by the school center. Before the study was carried out, both families and students were informed about the purpose of the study and an informed consent was provided, where the anonymity of the participants was ensured. All students belonging to the two selected groups participated in the study. However, there were two students in the experimental group whose responses were dismissed because they did not reach an $80 \%$ rate of attendance during the intervention. Once the required forms were obtained, questionnaires were administered at school during the PE class by a member of the research group. This person explained the importance that the results would have on their future physical education classes, emphasizing the anonymity 
of the participants and encouraging them to provide honest answers to the questions. The group to which they belong as well as the number of the list were also required to link their answers. Data were collected during the sessions right before and after the intervention in both groups.

The research was carried out during the COVID-19 pandemic (March-April 2021). During this time, there were national recommendations provided both by the Government [42] and COLEF (Professional Association of Physical Educators) [43], which may have affected the PE setting characteristics and, in turn, students' perceptions of their experience in PE. Specifically, groups were smaller than before, and students attended less PE lessons. In addition, the use of face masks was mandatory, and it was encouraged to minimize physical contact. Lastly, the materials had to be disinfected regularly. These guidelines could affect organizational features of the PE class since the teacher had less students in attendance but had many new elements to control (distance, masks, disinfection ... ). Furthermore, those changes could have also affected the interactions occurring during the lessons (due to the smaller size of the groups and the use of mask).

The practical proposal took place at a school in Madrid. During the didactic unit (DU), the SEM was put into practice during eight basketball sessions following the guidelines set out by Siedentop [22]. The control group followed the contents programmed by the school department. The sessions in this group were taught by the school's PE teacher, who had years of work experience, and were based on direct command. The sessions lasted for $50 \mathrm{~min}$ and were taught by traditional teaching, characterized by teacher-controlled decisions and teacher-directed engagement patterns for students. Skill drills to game play and high rates of practice and repetition were developed during the first five sessions. The last three sessions were dedicated to reduced competitive games applying all the skills practiced before.

Before the intervention, the teacher for the experimental group-who has previous knowledge and experience about SEM, as well with the students' groups-attended several meetings with the research group and was closely monitored on a day-to-day basis during the intervention. Following the indications by Manninen and Campbell [32] about the relevance of reporting the characteristics of the interventions in educational quasiexperimental studies, we provide a detailed description of the intervention carried out in the present study.

Once the dynamics were explained and the questionnaires were filled in, the students were organized into four teams by the teacher; within these teams, the roles were distributed (captain, coach, scorer, and physical trainer) by the students. Then, they filled in a sheet (attached at the end of the DU) and agreed on a team name.

At the beginning of each session, a few minutes were dedicated to the introduction of the session. Firstly, references to the technical-tactical contents that they were going to carry out were made; then, the students who had the specific role that the content was about explained the characteristics of that role within the team. The second session started by explaining the role of the captain. The third session was dedicated for the role of the referee/scorer and the fourth one for the role of the coach. At the same time, using guided discovery, the teacher tried to get the students to define the roles that they would be playing during practice and invited them to put each one into practice during the DU.

Table 1 shows the sessions and the specific characteristics of the SEM applied during the DU with the experimental group. 
Table 1. Sessions and presence of the SEM characteristics.

\section{Session}

Session 1. Driving and familiarization exercises with both the equipment and the sport. 3 March

\section{SEM Characteristics}

Affiliation. Team formation and team nomenclature, introduction of the SE model, and assignment of roles (captain, coach, scorer, and equipment manager). The definition and explanation of the functions of each role will be done at the beginning of sessions $2,3,4$, and 5 . For example, on the first day, at the beginning of the class during the introduction, the captains would have the floor.
Session 2. Bounce and pass. Practicing stops and starts. 4 March

Session 3. Explanation and practice of shooting at the basket; we start with the $3 \times 3$ game.

$$
17 \text { March }
$$

Session 4. The entry to the basket and the application of this content in real game situations. 18 March

Session 5. Dribbling, change of direction, and real play superiority in attack. 7 April

Assuming a season and affiliation. The captains explain the role of the captain within a team, they have the floor, and we ask them to exemplify real practical situations in which the captain's role is required. The season

has started, and the scorers have to write down the score of the second game that is part of the season.

Affiliation/Record keeping. The scorers explain the functions of the referees in the matches, we give the floor to the students who have this role within the team.

In the $3 \times 3$ game, two of the four scorers referee the matches. We ask for voluntary participation and we value it positively.

Affiliation. Explanation of the role of trainers. Each trainer is going to choose an activity to do and lead with the whole group (motivating, correcting...).

Formal competition. Game of the day that scores 3 vs. 2 by teams; each team will have its sheet and on it the session number with a box on the right to write down the score obtained. This is one of the main characteristics of the SEM, which helps to encourage the motivation of the students.

Culminating events. The final event begins. During this session, it is convenient to point out that we are going to start with the last games, and these are real game situations in which one of the main objectives and

Session 6. Basic defensive concepts explanation. 8 April aspects that we emphasize is the fact that our students will fulfil the roles

based on the functions based on the roles and respect the positions on the pitch.

Session 7. Review of the technical and tactical

Culminating events. The final group continues. Teams have their contents during the DU. 21 April warm-up and pre-match preparation time independently. The coaches are in charge of leading the warm-ups of each team.

Session 8. Real game situations in the form of mini-basketball. 22 April

Festivity/Culminating event/Record keeping. Final matches, prize giving, and speeches. All teams are recognized teams both high and low scorers are recognized; during this part of the UD, all students who have helped their team and fulfilled the requirements should feel important.

Note: The SEM characteristics present in each session have been highlighted with bold letter.

\subsection{Measures}

\subsubsection{Basic Psychological Needs}

The Basic Psychological Needs in Exercise Scale (BPNES) [44] adapted for a Spanish context [45] was used to measure the satisfaction of basic psychological needs. The instrument was preceded by the heading "During my PE classes ... " followed by 12 items (4 per factor), which measured the satisfaction of autonomy (e.g., "the way the exercises are carried out coincides perfectly with the way in which I want to do them"), satisfaction of competence (e.g., "I feel I have progressed greatly with respect to the final objective that I had set out for myself"), and the satisfaction of relatedness (e.g., "I feel very comfortable when I carry out the exercises with the other mates"). A 5-point Likert scale from 1 (strongly disagree) to 5 (strongly agree) was used to answer the questionnaire. The internal consistency of the instrument, measured by Cronbach's alpha, was adequate for both the pre-test and the post-test (pre/post autonomy: 0.81/0.70; pre/post competence: $0.70 / 0.75$; pre/post relatedness: $0.79 / 0.84)$. 


\subsubsection{Intrinsic Motivation}

The Intrinsic Motivation factor of the Spanish version [46] of the Perceived Locus of Causality (PLOC) [47] was used. The instrument was preceded by the heading ("I take part in my PE class ... " followed by four items, which measured the intrinsic motivation (e.g., "because physical education is fun"). A 5-point Likert scale from 1 (strongly disagree) to 5 (strongly agree) was used to answer the questionnaire. The internal consistency of the factor was adequate (Cronbach's alpha of 0.86 for the pre-test measure and 0.85 for the post-test measure).

\subsubsection{Behavioral Engagement}

The Engagement Questionnaire in PE [48] adapted for a Spanish context was used [11]. The instrument was preceded by the heading ("When I am in PE classes ... " followed by five items, which measured the behavioral engagement (e.g., "I listen to the teacher very carefully"). A 5-point Likert scale from 1 (strongly disagree) to 5 (strongly agree) was used to answer the questionnaire. The internal consistency of the factor was adequate (Cronbach's alpha of 0.77 for the pre-test measure and 0.83 for the post-test measure).

\subsection{Data Analysis}

Firstly, descriptive statistics were calculated, and Pearson correlations were performed among study variables. A Kolmogorov-Smirnov test was performed to verify the normality of the data and showed that it was non-parametric $(p<0.05)$. Thus, a Mann-Whitney test was performed to analyze possible differences between the groups before the intervention. Then, the main analysis was performed to investigate the intervention effects in two ways. First, to verify the intragroup differences between the pre-test and post-test data collection, a Wilcoxon test was performed with each of the groups. Next, a new Mann-Whitney test was conducted to analyze the intergroup differences between the two groups after the intervention. The SPSS 24.0 software program was used to process the data.

\section{Results}

Table 2 displays descriptive statistics and correlations among study variables. In general, significant correlations among adaptive variables were found in the overall sample. It is worth mentioning that the correlations were stronger after the intervention than before.

As shown in Table 3, significant differences were found between the groups before the intervention. The control group showed higher scores in autonomy and relatedness satisfaction.

Tables 4 and 5 show the effects of the intervention. In the experimental group, significant differences were found between before and after the intervention in the autonomy satisfaction variable, competence, relatedness, and behavioral engagement. In the four variables, the scores after the intervention were higher than before. However, only relatedness showed a significant difference between before and after the intervention in the control group. In this case, the scores decreased after the intervention. 
Table 2. Descriptive statistics and bivariate correlations of the study variables.

\begin{tabular}{|c|c|c|c|c|c|c|c|c|c|c|}
\hline & 1 & 2 & 3 & 4 & 5 & 6 & 7 & 8 & 9 & 10 \\
\hline 1. Pre Autonomy satisfaction & 1 & $0.442 * *$ & $0.421^{* *}$ & $0.592 * *$ & 0.211 & $-0.154^{* *}$ & -0.080 & -0.236 & -0.184 & -0.076 \\
\hline 2. Pre Competence satisfaction & & 1 & $0.633^{* *}$ & $0.614^{* *}$ & 0.244 & -0.085 & -0.038 & -0.124 & -0.213 & 0.071 \\
\hline 3. Pre Relatedness satisfaction & & & 1 & $0.536^{* *}$ & 0.265 & -0.123 & -0.202 & -0.277 & -0.235 & -0.093 \\
\hline 4. Pre Intrinsic motivation & & & & 1 & 0.192 & 0.017 & 0.065 & -0.136 & -0.068 & -0.108 \\
\hline 5. Pre Behavioral engagement & & & & & 1 & 0.045 & 0.061 & 0.162 & -0.064 & 0.211 \\
\hline 6. Post Autonomy satisfaction & & & & & & 1 & $0.559^{* *}$ & $0.401^{* *}$ & $0.635^{* *}$ & $0.480^{* *}$ \\
\hline 7. Post Competence satisfaction & & & & & & & 1 & $0.474^{* *}$ & $0.484^{* *}$ & $0.281^{* *}$ \\
\hline 8. Post Relatedness satisfaction & & & & & & & & 1 & 0.246 & $0.637^{* *}$ \\
\hline 10. Post Behavioral engagement & & & & & & & & & & 1 \\
\hline $\mathrm{M}(\mathrm{SD})$ & $\begin{array}{c}3.26 \\
(0.67)\end{array}$ & $\begin{array}{c}3.65 \\
(0.66)\end{array}$ & $\begin{array}{c}4.03 \\
(0.83)\end{array}$ & $\begin{array}{c}3.83 \\
(0.87)\end{array}$ & $\begin{array}{c}4.08 \\
(0.56)\end{array}$ & $\begin{array}{c}3.45 \\
(0.54)\end{array}$ & $\begin{array}{c}3.91 \\
(0.64)\end{array}$ & $\begin{array}{c}4.11 \\
(0.76)\end{array}$ & $\begin{array}{c}3.76 \\
(0.63)\end{array}$ & $\begin{array}{c}4.38 \\
(0.49)\end{array}$ \\
\hline
\end{tabular}


Table 3. Differences between groups before the intervention.

\begin{tabular}{ccccc}
\hline & $\begin{array}{c}\text { Control Group }(\boldsymbol{n}=\mathbf{2 5}) \\
\text { M (SD) }\end{array}$ & $\begin{array}{c}\text { Experimental Group } \\
(\boldsymbol{n}=\mathbf{2 5}) \mathbf{M} \text { (SD) }\end{array}$ & Z & $\boldsymbol{p}$ \\
\hline Autonomy satisfaction & $3.44(0.68)$ & $3.09(0.62)$ & -2.02 & 0.04 \\
Competence satisfaction & $3.82(0.45)$ & $3.48(0.79)$ & -1.52 & 0.12 \\
Relatedness satisfaction & $4.28(0.60)$ & $3.79(0.96)$ & -1.76 & 0.07 \\
Intrinsic motivation & $3.71(0.91)$ & $3.96(0.84)$ & -0.92 & 0.35 \\
Behavioral engagement & $4.12(0.58)$ & $4.05(0.54)$ & -0.32 & 0.74 \\
\hline
\end{tabular}

Table 4. Comparison of effects of intervention.

\begin{tabular}{|c|c|c|c|c|c|c|c|}
\hline \multirow{2}{*}{ Title 1} & & \multicolumn{3}{|c|}{ Control Group $(n=25)$} & \multicolumn{3}{|c|}{ Experimental Group $(n=25)$} \\
\hline & & $\mathrm{M}(\mathrm{SD})$ & $\mathbf{Z}$ & $p$ & $\mathrm{M}(\mathrm{SD})$ & $\mathbf{Z}$ & $p$ \\
\hline Autonomy satisfaction & $\begin{array}{l}\text { Pre } \\
\text { Post }\end{array}$ & $\begin{array}{c}3.44(0.68) \\
3.27(44)\end{array}$ & -0.804 & 0.421 & $\begin{array}{l}3.09(0.62) \\
3.63(0.58)\end{array}$ & -2.688 & 0.007 \\
\hline Competence satisfaction & $\begin{array}{l}\text { Pre } \\
\text { Post }\end{array}$ & $\begin{array}{c}3.82(0.45) \\
3.66(64)\end{array}$ & -1.045 & 0.296 & $\begin{array}{l}3.48(0.79) \\
4.17(0.52)\end{array}$ & -3.068 & 0.002 \\
\hline Relatedness satisfaction & $\begin{array}{l}\text { Pre } \\
\text { Post }\end{array}$ & $\begin{array}{l}4.28(0.60) \\
3.79(0.84)\end{array}$ & -1.968 & 0.049 & $\begin{array}{l}3.79(0.96) \\
4.43(0.50)\end{array}$ & -2.565 & 0.010 \\
\hline Intrinsic motivation & $\begin{array}{l}\text { Pre } \\
\text { Post }\end{array}$ & $\begin{array}{l}3.71(0.91) \\
3.58(0.51)\end{array}$ & -0.756 & 0.449 & $\begin{array}{l}3.96(0.84) \\
3.95(0.69)\end{array}$ & -0.72 & 0.943 \\
\hline Engagement & $\begin{array}{l}\text { Pre } \\
\text { Post }\end{array}$ & $\begin{array}{l}4.12(0.58) \\
4.28(0.53)\end{array}$ & -1.537 & 0.124 & $\begin{array}{l}4.05(0.54) \\
4.48(0.43)\end{array}$ & -2.721 & 0.007 \\
\hline
\end{tabular}

Table 5. Differences between groups after the intervention.

\begin{tabular}{ccccc}
\hline & $\begin{array}{c}\text { Control Group }(\boldsymbol{n}=\mathbf{2 5}) \\
\text { M (SD) }\end{array}$ & $\begin{array}{c}\text { Experimental Group } \\
(\boldsymbol{n}=\mathbf{2 5}) \mathbf{M} \text { (SD) }\end{array}$ & Z & $p$ \\
\hline Autonomy satisfaction & $3.27(0.44)$ & $3.63(0.58)$ & -2.634 & 0.008 \\
Competence satisfaction & $3.66(0.64)$ & $4.17(0.52)$ & -2.731 & 0.006 \\
Relatedness satisfaction & $3.79(0.84)$ & $4.43(0.50)$ & -2.897 & 0.004 \\
Intrinsic motivation & $3.58(0.51)$ & $3.95(0.69)$ & -2.463 & 0.014 \\
Behavioral engagement & $4.28(0.53)$ & $4.48(0.43)$ & -1.260 & 0.208 \\
\hline
\end{tabular}

\section{Discussion}

The main aim of the present study was to analyze the effect of a SEM-based teaching intervention on students' BPN, intrinsic motivation, and behavioral engagement in physical education.

First of all, it is important to notice that there were differences in the motivational variables between the control and experimental group before the intervention. This fact seems to be a common situation in educational research given that the groups establishment is not random, but they have been previously formed by the school [49-51]. In the present study, the control group showed greater autonomy and relatedness satisfaction. After the intervention, not only had these differences been eliminated, but the students in the experimental group surpassed the scores of the control group in the aforementioned variables.

The changes observed in the experimental group suggest that a SEM-based intervention in PE can foster motivational processes among students. More specifically, it was found that students who followed a SEM-based DU improved their BPN satisfaction as well as their behavioral engagement. These findings are in line with previous works aiming to understand how SEM might affect students' motivation $[34,52,53]$. The enhancement of motivational variables in the experimental group after the intervention could be due to certain characteristics that SEM presents. 
Autonomy seems to be nurtured by the student-led feature of the SEM [32]. The sense of volition in this methodological approach becomes patent in the possibility for students to make some decisions (such select team names or team flags), which has been suggested to foster autonomy in this context [54]. Furthermore, students might feel their autonomy is satisfied when taking specific roles or assuming certain responsibilities. Although most of the existing literature has suggested the positive role of SEM to foster autonomy satisfaction, it seems that there might be certain conditions under which this methodology does not support autonomy as much as other approaches do [55,56]. It is thus interesting to note that the uncommon characteristics under which this study was performed, because of the COVID-19 measures adopted in Spain, do not seem to act like a barrier for the benefits of the SEM when it comes to analyzing autonomy satisfaction. While the formal competition, which required experimentation or creativity, seemed to have organizational problems in order to meet pandemic measures, such as maintaining security distance or lower ratios in class, it might be assumed as autonomy frustration. However, the fact that students were able to lead different sessions or make their own choices, such as select roles or establish a team name and colors, finally improved autonomy levels.

As for competence satisfaction, the findings in the present study revealed an important increase in the experimental group during the intervention (3.48 vs. 4.17). The improvement in the competence satisfaction among the students in the experimental group is especially relevant given that some studies have found negative effects of SEM on competence satisfaction when compared with other models [56,57], probably because of the lack of SEM prescription of instructional strategies for developing skill and tactical knowledge [58]. However, SEM features provide several opportunities for students to feel competent. For instance, the establishment of roles (which, as mentioned earlier, can also contribute to the experience of autonomy satisfaction) give the students the chance to display their strengths among their peers. When teaching through other methodological approaches (traditional style, drills, and practice method), students' performance is exclusively valued in terms of their physical achievements. However, within the SEM, students adopt different roles (coach, team manager, journalist ... ) requiring skills beyond mere physical execution. This fact might explain why SEM has been shown to have relevant and positive effects on unmotivated students $[35,59]$. The systematic record developed during the DU also provided each student an opportunity to both receive feedback on their performance [60,61] and identify different aspects to assess peers'. Furthermore, offering the opportunity to manage more unit content might allow students to engage with it, which will be required while observing their peers or demonstrating skills [58]. Structuring and planning lessons by, for example, setting clear objectives before the activities, also enhances competence in learning environments [62], and this can be easily seen in the SEM, where students are provided with the entire information about what they are going to do and about what the teacher expects from them.

Students in the experimental group also improved their relatedness satisfaction. It is worth mentioning that this BPN is the only BPN found to have all positive effects in the recent systematic review carried out by Manninen and Campbell [32]. Despite these overwhelming figures, SEM has received some critics, pointing out that this methodology might promote discrimination and exclusion based on skill level, but also on gender differences [58]. When looking at the SEM implementation, it must be considered that the SEM core features, such as affiliation, formal competition, or record keeping, require high levels of teamwork (rather than individual tasks), and this may well foster students' relatedness satisfaction. The fact that the students work in a team through the entire DU is likely to foster a feeling of connection and belonging [63]. This sense might be stimulated by the competitive context in which peer interactions occur. The need to face problems and challenges emerging during the season might help students to be aware of how important it is to collaborate in order to succeed [64]. Considering the above, our findings support more recent literature that indicates the SEM is generally an inclusive model if implemented correctly [27], even in the COVID-19 scenario. 
Our findings revealed that, together with students' BPN satisfaction, their behavioral engagement increased in the experimental group during the intervention. In line with previous studies, the satisfaction of autonomy, competence, and relatedness showed a positive relationship with students' behavioral engagement [65]. These authors also suggested that within BPN satisfaction, students will improve their autonomous motivation and, consequently, their engagement. Along the same lines, other authors have shown a direct relationship between autonomy and engagement by supporting and enhancing students' self-confidence and the sense of freedom during the activities $[6,66,67]$. For example, Ntoumanis [68] highlighted the importance of nurturing competence due to the positive consequences associated with wellbeing [16] or enjoyment in PE classes [69]. As well, students will be engaged when they establish social connections and improve the communication with both peers and teacher, which satisfies the need for relatedness [70]. Using an observational methodology, a recent work suggested that structure during activity and relatedness support could positively predict student engagement [10]. The results of the present study align with this finding given that, as mentioned earlier, the SEM seems to be a valid tool to enhance structure during activities as well as to support relatedness within the PE setting.

Surprisingly, although it was hypothesized, intrinsic motivation levels did not increase after the intervention. It is important to note that the construct of intrinsic motivation could be less likely to be affected by the immediate experience than the BPN satisfaction. That is, when a student feels (or does not feel) intrinsically motivated towards PE, this feeling is difficult to alter through an eight-session intervention. However, students could more easily identify and report whether the activities they engaged in can support their autonomy, competence, or relatedness. Franco, et al. [71], in a study aiming to understand motivational processes among low-motivation students, found that the role of intrinsic motivation was not as relevant as it was expected to be. More specifically, an explanatory model of students' intention to be physically active was tested and the findings of the result revealed that intrinsic motivation did not directly predict such intention. However, it indirectly predicted the intention of being physically active through dispositional flow. These findings together with the results of the present study, and in line with Csikszentmihalyi et al. [72] and other studies [73], suggested that phenomenological experience (reflected in the flow experience or the BPN satisfaction) is a powerful source that can predict adaptive behavioral patterns (such as intention to be physically active in Franco et al.'s work or behavioral engagement in the present study). It would be interesting for future studies to address whether intrinsic motivation is more likely to be influenced through longer interventions as well as to further explore to what extent behavior can be altered through pedagogical interventions without necessarily modifying motivational regulations.

As for the students in the control group, taught through a traditional methodology, not only did they not show improvements in the study variables, but a decrease was found in the relatedness satisfaction during the intervention. It is interesting to note how different the trends were for the two groups regarding this variable (the control group decreased 0.49 points, while the experimental group increased 0.64 points on their scores on relatedness satisfaction). These findings highlight the relevance of pedagogical approaches on students' feelings of relatedness, in line with previous studies findings both in PE $[50,74,75]$ and other settings [76,77]. As mentioned earlier, the SEM gathers several characteristics that can naturally foster connections among students and it explains why most existing literature has found that this methodology fosters relatedness [32]. On the other hand, traditional teaching has traditionally been considered a teacher-centered approach in which decisions about planning, instruction, and assessment are all made by teachers [78]. When taught through this methodological model, students are likely to assume a more passive and reproductive role [79,80]. Its focus being on the acquisition of motor skills, traditional teaching has been suggested to fail in the promotion of social processes [81]. It would thus be possible that students in the control group of the present 
study felt that their relatedness need was being undermined during the basketball DU due to the scarcity of situations allowing for an interaction among peers.

This study presents some limitations that should be mentioned. The first one is related to the sample size. The small group sizes were due to the difficulties of conducting an intervention study in a structured educational context and, in addition, in the COVID-19 scenario and ratio restrictions. Despite that these particular conditions will no longer being replicable, it would be interesting to use a larger sample size in future studies, which would allow us to apply predictive statistical techniques to determine whether the changes produced in motivational variables may be due to changes produced by another variable. Furthermore, the differences found between groups before the intervention as well as the presence of two different teachers could have an effect on the final results. Standardized groups conditions would be useful for future studies. Furthermore, the fact that the intervention was developed in one specific content might be a limitation; it would be interesting to explore how motivational processes are affected by the role of different contents. Finally, even though the positive effect of SEM has been proven in PE context, there are still some limitations that suggest to keep exploring to enlarge the knowledge in this line [82] and to apply this model in the real context with proper adaptations.

The present study allowed us to better understand the influence that changes in some didactical and methodological aspects of the PE class have on students' motivation by exploring the relationships between student engagement, BPN, and intrinsic motivation. The results obtained in this research, which was carried out in COVID-19 context, do not greatly differ from those found in other studies developed in ordinary contexts with the SEM.

Surprisingly, relatedness need levels were different after the intervention. In addition to the sample size limitation, the fact that there was no effect of the intervention on the satisfaction of relatedness, a variable that could be more difficult to modify, should be considered in future studies carrying out longer interventions. In that line, some questions emerged around the SEM characteristics: Does the teacher's role experienced by students frustrate this basic need? Does the SEM promote feeling of relatedness between teams or just within teams? Does the SEM promote relatedness between students and teachers or just between students? These are questions that researchers may look to pursue in the future.

\section{Conclusions}

The main objective of the present study was to analyze the effect that a SEM intervention developed in the COVID-19 scenario had on different students' motivational outcomes in the PE class. The results showed that, when students are taught following the SEM, they can improve their autonomy, competence, and relatedness needs satisfaction within the PE class. Furthermore, it was found that the use of the aforementioned methodology can enhance students' behavioral engagement. These findings thus suggest that, even under extraordinary circumstances, the SEM seems to be a valid methodological approach to enhance positive motivational patterns among students within the PE context.

Author Contributions: Conceptualization, C.T.; Data curation, A.G.-P.; Formal analysis, E.F.; Funding acquisition, E.F.; Investigation, A.G.-P.; Methodology, E.F. and C.T.; Supervision, J.C. All authors have read and agreed to the published version of the manuscript.

Funding: This work was supported by Universidad Pontificia Comillas (Project entitled Analysis of the Interactions in Physical Education Setting through Observational Methodology: Application of Machine Learning Techniques in Education; PP2021_03) and Agencia Estatal de Investigación from Spain (PID2020-114051RA-I00/AEI /10.13039/501100011033).

Institutional Review Board Statement: The study was conducted according to the guidelines of the Declaration of Helsinki, and approved by the Ethics Committee of Universidad Politécnica de Madrid (16 May 2017).

Informed Consent Statement: Informed consent was obtained from all subjects involved in the study. 
Data Availability Statement: Data available on request due to restrictions eg privacy or ethical.

Conflicts of Interest: The authors declare no conflict of interest.

\section{References}

1. Langford, R.; Bonell, C.; Jones, H.; Pouliou, T.; Murphy, S.; Waters, E.; Komro, K.; Gibbs, L.; Magnus, D.; Campbell, R. The World Health Organization's Health Promoting Schools framework: A Cochrane systematic review and meta-analysis. BMC Public Health 2015, 15, 130. [CrossRef] [PubMed]

2. Curran, T.; Standage, M. Psychological needs and the quality of student engagement in physical education: Teachers as key facilitators. J. Teach. Phys. Educ. 2017, 36, 262-276. [CrossRef]

3. Cañabate, D.; Tesouro, M.; Puiggali, J.; Zagalaz, M.L. Estado actual de la Educación Física desde el punto de vista del profesorado. Propuestas de mejora. Retos 2019, 35, 47-53.

4. Fredricks, J.A.; Blumenfeld, P.C.; Paris, A.H. School engagement: Potential of the concept, state of the evidence. Rev. Educ. Res. 2004, 74, 59-109. [CrossRef]

5. Furrer, C.; Skinner, E.A. Sense of relatedness as a factor in children's academic engagement and performance. J. Educ. Psychol. 2003, 95, 148-162. [CrossRef]

6. Reeve, J.; Jang, H.; Carrell, D.; Jeon, S.; Barch, J. Enhancing students' engagement by increasing teachers' autonomy support. Motiv. Emot. 2004, 28, 147-169. [CrossRef]

7. Skinner, E.A.; Kindermann, T.A.; Connell, J.P.; Wellborn, J.G. Engagement and disaffection as organizational constructs in the dynamics of motivational development. In Handbook of Motivation at School; Educational psychology handbook series; Routledge/Taylor \& Francis Group: New York, NY, USA, 2009; pp. 223-245.

8. Skinner, E.A.; Furrer, C.; Marchand, G.; Kindermann, T.A. Engagement and disaffection in the classroom: Part of a larger motivational dynamic? J. Educ. Psychol. 2008, 100, 765-781. [CrossRef]

9. Hospel, V.; Galand, B.; Janosz, M. Multidimensionality of behavioural engagement: Empirical support and implications. Int. J. Educ. Res. 2016, 77, 37-49. [CrossRef]

10. González-Peño, A.; Franco, E.; Coterón, J. Do observed teaching behaviors relate to students' engagement in physical education? Int. J. Environ. Res. Public Health 2021, 18, 2234. [CrossRef] [PubMed]

11. Coterón, J.; Franco, E.; Ocete, C.; Pérez-Tejero, J. Teachers' psychological needs satisfaction and thwarting: Can they explain students' behavioural engagement in physical education? A multi-level analysis. Int. J. Environ. Res. Public Health 2020, 17, 8573. [CrossRef]

12. Geen, R.G. Human Motivation: A Social Psychological Approach; Thomson Brooks/Cole Publishing Co: Belmont, CA, USA, 1995.

13. Franco, E.; Coterón, J.; Gómez, V.; Brito, J.; Martínez, H.A. Influencia de la motivación y del flow disposicional sobre la intención de realizar actividad físico-deportiva en adolescentes de cuatro países. Retos 2017, 31, 46-51.

14. Méndez-Giménez, A.; Cecchini, J.A.; Fernández-Río, J.; González, C. Autodeterminación y metas sociales: Un modelo estructural para comprender la intención de práctica, el esfuerzo y el aburrimiento en Educación Física. Aula Abierta 2012, 40, 51-62.

15. Deci, E.L.; Ryan, R.M. Intrinsic Motivation and Self-Determination in Human Behaviour; Plenum: New York, NY, USA, 1985.

16. Deci, E.L.; Ryan, R.M. Self-determination theory and the facilitation of intrinsic motivation, social development, and well-being. Am. Psychol. 2000, 55, 68-78.

17. Ryan, R.M.; Deci, E.L. Intrinsic and extrinsic motivation from a self-determination theory perspective: Definitions, theory, practices, and future directions. Contemp. Educ. Psychol. 2020, 61, 101860. [CrossRef]

18. Vansteenkiste, M.; Ryan, R.M.; Soenens, B. Basic psychological need theory: Advancements, critical themes, and future directions. Motiv. Emot. 2020, 44, 1-31. [CrossRef]

19. Mizios, D.; Digelidis, N.; Goudas, M.; Papaioannou, A. The effects of reciprocal and self-check teaching styles in intrinsic-extrinsic motivation and lesson satisfaction in physical education. Inq. Sport Phys. Educ. 2009, 7, 254-264.

20. Hwang, Y.; Jin, J. How does student motivation affect different teaching styles and students engagement in physical education? J. Phys. Educ. Recreat. Danc. 2016, 87, 61. [CrossRef]

21. García-González, L.; Abós, Á.; Diloy-Peña, S.; Gil-Arias, A.; Sevil-Serrano, J. Can a hybrid sport education/teaching games for understanding volleyball unit be more effective in less motivated students? An examination into a set of motivation-related variables. Sustainability 2020, 12, 6170. [CrossRef]

22. Siedentop, D. Sport Education: Quality PE through Positive Sport Experiences; Human Kinetics: Champaign, IL, USA, 1994.

23. Bessa, C.; Hastie, P.; Rosado, A.; Mesquita, I. Sport education and traditional teaching: Influence on students' empowerment and self-confidence in high school physical education classes. Sustainability 2021, 13, 578. [CrossRef]

24. Wallhead, T.L.; Garn, A.C.; Vidoni, C. Effect of a sport education program on motivation for physical education and leisure-time physical activity. Res. Q. Exerc. Sport 2014, 85, 478-487. [CrossRef]

25. Siedentop, D. What is sport education and how does it work? J. Phys. Educ. Recreat. Danc. 1998, 69, 18-20. [CrossRef]

26. Siedentop, D.; Hastie, P.H.; Van der Mars, H. Complete Guide to Sport Education, 2nd ed.; Human Kinetics: Champaign, IL, USA, 2011.

27. Harvey, S.; Pill, S.; Hastie, P.; Wallhead, T. Physical education teachers' perceptions of the successes, constraints, and possibilities associated with implementing the sport education model. Phys. Educ. Sport Pedagog. 2020, 25, 555-566. [CrossRef] 
28. Gutiérrez, D.; Segovia, Y.; García-López, L.M.; Sánchez-Mora, D. Evaluation of a program to expand use of sport education model: Teachers' perception and experience. J. Hum. Sport Exerc. 2020, 15, 345-358. [CrossRef]

29. Puente-Maxera, F.; Méndez-Giménez, A.; Martínez de Ojeda, D. Games from around the world: Promoting intercultural competence through sport education in secondary school students. Int. J. Intercult. Relat. 2020, 75, 23-33. [CrossRef]

30. Calderón, A.; Martínez de Ojeda, D.; Valverde, J.J.; Méndez-Giménez, A. “Ahora nos ayudamos más": Docencia compartida y clima social de aula. Experiencia con el modelo de Educación Deportiva. RICYDE. Rev. Int. Cienc. Deporte 2016, 12, 121-136. [CrossRef]

31. Gutiérrez, D.; García-López, L.M.; Hastie, P.A.; Segovia, Y. Adoption and fidelity of Sport Education in Spanish schools. Eur. Phys. Educ. Rev. 2021, 1-19. [CrossRef]

32. Manninen, M.; Campbell, S. The effect of the Sport Education Model on basic needs, intrinsic motivation and prosocial attitudes: A systematic review and multilevel meta-analysis. Eur. Phys. Educ. Rev. 2021, 1-22. [CrossRef]

33. Cuevas, R.; García-López, L.M.; Contreras, O. Influencia del modelo de Educación Deportiva en las necesidades psicológicas básicas. Cuad. Psicol. Deporte 2015, 15, 155-162. [CrossRef]

34. Gil-Arias, A.; Claver, F.; Práxedes, A.; Villar, F.D.; Harvey, S. Autonomy support, motivational climate, enjoyment and perceived competence in physical education: Impact of a hybrid teaching games for understanding/sport education unit. Eur. Phys. Educ. Rev. 2018, 26, 36-53. [CrossRef]

35. Perlman, D. The influence of the Sport Education Model on amotivated students' in-class physical activity. Eur. Phys. Educ. Rev. 2012, 18, 335-345. [CrossRef]

36. Baena-Morales, S.; López-Morales, J.; García-Taibo, O. La intervención docente en educación física durante el periodo de cuarentena por COVID-19. Retos 2021, 39, 388-395. [CrossRef]

37. O’Brien, W.; Adamakis, M.; O’ Brien, N.; Onofre, M.; Martins, J.; Dania, A.; Makopoulou, K.; Herold, F.; Ng, K.; Costa, J. Implications for European Physical Education Teacher Education during the COVID-19 pandemic: A cross-institutional SWOT analysis. Eur. J. Teach. Educ. 2020, 43, 503-522. [CrossRef]

38. Varea, V.; González-Calvo, G. Touchless classes and absent bodies: Teaching physical education in times of COVID-19. Sport Educ. Soc. 2021, 26, 831-845. [CrossRef]

39. Cao, W.; Fang, Z.; Hou, G.; Han, M.; Xu, X.; Dong, J.; Zheng, J. The psychological impact of the COVID-19 epidemic on college students in China. Psychiatry Res. 2020, 287, 1-12. [CrossRef]

40. Duong, V.; Luo, J.; Pham, P.; Yang, T.; Wang, Y. The ivory tower lost: How college students respond differently than the general public to the COVID-19 pandemic. In Proceedings of the 2020 IEEE/ACM International Conference on Advances in Social Networks Analysis and Mining (ASONAM), The Hague, The Netherlands, 7-10 December 2020; pp. 126-130.

41. Association, A.P. Ethical principles of psychologists and code of conduct. Am. Psychol. 2002, 57, 1060-1073. [CrossRef]

42. Real Decreto 463/2020, d.d.m., por el que se Declara el Estado de Alarma para la Gestión de la Situación de Crisis Sanitaria Ocasionada por el COVID-19. 25390-25400. Available online: https://www.boe.es/eli/es/rd/2020/03/14/463/dof/spa/pdf (accessed on 9 November 2021).

43. Colef, C. Recomendaciones docentes para una educación física escolar segura y responsable ante la "nueva normalidad". Minimización de riesgos de contagio de la COVID-19 en las clases de EF para el curso 2020-2021. Rev. Española Educ. Física Y Deportes 2020, 429, 81-93.

44. Vlachopoulos, S.; Michailidou, S. Development and initial validation of a measure of autonomy, competence and relatedness: The Basic Psychological Needs in Exercise Scale. Meas. Phys. Educ. Exerc. Sci. 2006, 10, 179-201. [CrossRef]

45. Moreno, J.A.; González-Cutre, D.; Chillón, M.; Parra, N. Adaptación a la educación física de la escala de las necesidades psicológicas básicas en el ejercicio. Rev. Mex. Psicol. 2008, 25, 295-303.

46. Moreno, J.A.; González-Cutre, D.; Chillón, M. Preliminary validation in Spanish of a scale designed to measure motivation in physical education classes: The Perceived Locus of Causality (PLOC) Scale. Span. J. Psychol. 2009, 12, 327-337. [CrossRef]

47. Goudas, M.; Biddle, S.; Fox, K. Perceived locus of causality, goal orientations, and perceived competence in school physical education classes. Br. J. Educ. Psychol. 1994, 64, 453-463. [CrossRef]

48. Shen, B.; McCaughtry, N.; Martin, J.; Fahlman, M.; Garn, A. Urban highschool girls' sense of relatedness and their engagement in Physical Education. J. Teach. Phys. Educ. 2012, 31, 231-245. [CrossRef]

49. Amado, D.; Del Villar, F.; Leo, F.M.; Sánchez-Oliva, D.; Sánchez-Miguel, P.A.; García-Calvo, T. Effect of a multi-dimensional intervention programme on the motivation of physical education students. PLoS ONE 2014, 9, e85275. [CrossRef]

50. Franco, E.; Coterón, J. The effects of a physical education intervention to support the satisfaction of basic psychological needs on the motivation and intentions to be physically active. J. Hum. Kinet. 2017, 59, 5-15. [CrossRef] [PubMed]

51. González-Cutre, D.; Ferriz, R.; Beltrán-Carrillo, V.J.; Andrés-Fabra, J.A.; Montero-Carretero, C.; Cervelló, E.; Moreno-Murcia, J.A. Promotion of autonomy for participation in physical activity: A study based on the trans-contextual model of motivation. Educ. Psychol. 2014, 34, 367-384. [CrossRef]

52. Burgueño, R.; Cueto-Martín, B.; Medina-Casaubón, J. Influencia de la educación deportiva sobre la respuesta motivacional del alumnado de bachillerato: Una perspectiva de género. Retos 2019, 37, 546-555. [CrossRef]

53. Viciana, J.; Casado-Robles, C.; Pérez-Macías, L.; Mayorga-Vega, D. A sport education teaching unit as a citizenship education strategy in physical education. A grouprandomized controlled trial. Retos 2020, 38, 44-52. 
54. De Meester, A.; Van Duyse, F.; Aelterman, N.; De Muynck, G.-J.; Haerens, L. An experimental, video-based investigation into the motivating impact of choice and positive feedback among students with different motor competence levels. Phys. Educ. Sport Pedagog. 2020, 25, 361-378. [CrossRef]

55. Fernández-Río, J.; Méndez-Giménez, A.; Méndez-Alonso, D. Efects of two instructional approaches, sport education and direct instruction, on secondary education students' psychological response. Sport TK Rev. Euroam. Cienc. Deporte 2017, 6, 9-20. [CrossRef]

56. Perlman, D. Change in affect and needs satisfaction for amotivated students within the sport education model. J. Teach. Phys. Educ. 2010, 29, 433-445. [CrossRef]

57. Perlman, D.J. Examination of self-determination within the sport education model. Asia-Pac. J. Health Sport Phys. Educ. 2011, 2, 79-92. [CrossRef]

58. Hastie, P.A.; Wallhead, T. Models-based practice in physical education: The case for sport education. J. Teach. Phys. Educ. 2016, 35, 390-399. [CrossRef]

59. Perlman, D.; Caputi, P. Examining the influence of sport education on the precursors of amotivation. Eur. Phys. Educ. Rev. 2016, 23, 212-222. [CrossRef]

60. Mouratidis, A.; Vansteenkiste, M.; Lens, W.; Sideridis, G. The motivating role of positive feedback in sport and physical education: Evidence for a motivational model. J. Sport Exerc. Psychol. 2008, 30, 240-268. [CrossRef] [PubMed]

61. De Muynck, G.J.; Vansteenkiste, M.; Delrue, J.; Aelterman, N.; Haerens, L.; Soenens, B. The effects of feedback valence and style on need satisfaction, self-talk, and perseverance among tennis players: An experimental study. J. Sport Exerc. Psychol. 2017, 39, 67-80. [CrossRef] [PubMed]

62. Aelterman, N.; Vansteenkiste, M.; Haerens, L.; Soenens, B.; Fontaine, J.R.J.; Reeve, J. Toward an integrative and fine-grained insight in motivating and demotivating teaching styles: The merits of a circumplex approach. J. Educ. Psychol. 2019, 111, 497-521. [CrossRef]

63. Perlman, D.; Goc Karp, G. A self-determined perspective of the sport education model. Phys. Educ. Sport Pedagog. 2010, 15, 401-418. [CrossRef]

64. Chu, T.L.; Zhang, T. Motivational processes in sport education programs among high school students: A systematic review. Eur. Phys. Educ. Rev. 2018, 24, 372-394. [CrossRef]

65. Jang, H.; Reeve, J.; Deci, E.L. Engaging students in learning activities: It is not autonomy support or structure but autonomy support and structure. J. Educ. Psychol. 2010, 102, 588-600. [CrossRef]

66. Gagné, M. The role of autonomy support and autonomy orientation in prosocial behavior engagement. Motiv. Emot. 2003, 27, 199-223. [CrossRef]

67. Jang, H.; Kim, E.J.; Reeve, J. Longitudinal test of self-determination theory's motivation mediation model in a naturally occurring classroom context. J. Educ. Psychol. 2012, 104, 1175-1188. [CrossRef]

68. Ntoumanis, N. A self-determination theory perspective on motivation in sport and physical education: Current trends and possible future research directions. In Advances in Motivation in Sport and Exercise, 3rd ed.; Roberts, G.C., Treasure, D.C., Eds.; Human Kinetics: Champaign, IL, USA, 2012; pp. 91-128.

69. Gråstén, A.; Jaakkola, T.; Liukkonen, J.; Watt, A.; Yli-Piipari, S. Prediction of enjoyment in school physical education. J. Sports Sci Med. 2012, 11, 260-269.

70. Moreno, J.A.; Hernández, A.; González-Cutre, D. Complementando la teoría de la autodeterminación con las metas sociales: Un estudio sobre la diversión en educación física. Rev. Mex. Psicol. 2009, 26, 213-222.

71. Franco, E.; Coterón, J.; Huéscar, E.; Moreno-Murcia, J.A. A person-centered approach in physical education to better understand low-motivation students. J. Teach. Phys. Educ. 2020, 39, 91-101. [CrossRef]

72. Csikszentmihalyi, M.; Abuhamdeh, S.; Nakamura, J. Flow. In Flow and the Foundations of Positive Psychology: The Collected Works of Mihaly Csikszentmihalyi; Csikszentmihalyi, M., Ed.; Springer: Dordrecht, The Netherlands, 2005; pp. $227-238$.

73. Franco, E.; Coterón, J.; Gómez, V.; Laura de Franza, A. Relación entre motivación, actividad física realizada en el tiempo libre y la intención futura de práctica de actividad física. Estudio comparativo entre adolescentes argentinos y españoles. Sport TK Rev. Euroam. Cienc. Deporte 2017, 6, 25-34. [CrossRef]

74. Cuevas-Campos, R.; Fernández-Bustos, J.G.; González-Cutre, D.; Hernández-Martínez, A. Need satisfaction and need thwarting in physical education and intention to be physically active. Sustainability 2020, 12, 7312. [CrossRef]

75. Méndez-Giménez, A.; Martínez de Ojeda, D.; Valverde, J.J. Inteligencia emocional y mediadores motivacionales en una temporada de Educación Deportiva sobre mimo. Ágora 2017, 17, 52-72. [CrossRef]

76. Van Roy, R.; Zaman, B. Unravelling the ambivalent motivational power of gamification: A basic psychological needs perspective. Int. J. Hum. Comput. Stud. 2019, 127, 38-50. [CrossRef]

77. Sailer, M.; Hense, J.U.; Mayr, S.K.; Mandl, H. How gamification motivates: An experimental study of the effects of specific game design elements on psychological need satisfaction. Comput. Hum. Behav. 2017, 69, 371-380. [CrossRef]

78. Mosston, M.; Ashworth, S. Teaching Physical Education, 1st online ed.; The Spectrum Institute for Teaching and Learning, 2008.

79. Rosado, A.; Mesquita, I. Melhorar a aprendizagem optimizando a instrução. In Pedagogia do Desporto; Rosado, A., Mesquita, I., Eds.; Edições FMH—UTL: Lisboa, Portugal, 2009; pp. 69-130.

80. Rosenshine, B. Content, time and direct instruction. In Concepts, Findings and Implications; Peterson, P., Walberg, H., Eds.; Mccutchan: San Pablo, CA, USA, 1979. 
81. Reeve, J.; Lee, W. Students' classroom engagement produces longitudinal changes in classroom motivation. J. Educ. Psychol. 2014, 106, 527-540. [CrossRef]

82. Hastie, P.A.; Martínez de Ojeda, D.; Calderón-Luquin, A. A review of research on Sport Education: 2004 to the present. Phys. Educ. Sport Pedagog. 2011, 16, 103-132. [CrossRef] 